\title{
Stress-induced hemorrhagic gastric ulcer after successful Helicobacter pylori eradication: two case reports
}

\author{
Mitsuru Moriya ${ }^{1 *}$, Akira Uehara $^{2}$, Toshikatsu Okumura $^{3}$, Mitsuaki Miyamoto ${ }^{1}$ and Yutaka Kohgo ${ }^{4}$
}

\begin{abstract}
Introduction: Helicobacter pylori infection is a major cause of gastric ulcers, and Helicobacter pylori eradication drastically reduces ulcer recurrence. It has been reported, however, that severe physical stress is closely associated with gastric ulceration even in Helicobacter pylori -negative patients.

Case presentation: We report the cases of a 47-year-old Japanese man and a 69-year-old Japanese man who developed psychological stress-induced hemorrhagic gastric ulcers, in both of whom Helicobacter pylori had been successfully eradicated.

Conclusion: Our cases strongly suggest that not only physical but also psychological stress is still an important pathogenic factor for peptic ulceration and accordingly that physicians should pay attention to the possible presence of psychological stress in the management of patients with peptic ulcers.
\end{abstract}

\section{Introduction}

Since Selye [1] reported that stress induces gastrointestinal ulcers, stress has been a major pathogenic factor for peptic ulceration. It is now well-documented, however, that Helicobacter pylori $(\mathrm{Hp})$ infection is a major cause of peptic ulcers and that $\mathrm{Hp}$ eradication drastically reduces ulcer recurrence, thereby understating or even excluding the importance of stress in ulcer formation.

On the other hand, there is increasing evidence that peptic ulcers can occur even in patients without chronic $H p$ infection or the use of non-steroidal anti-inflammatory drugs (NSAIDs). Chen et al. [2] examined 32 non- $H p$ and non-NSAID duodenal ulcer cases and reported that $15.6 \%$ of the cases were closely associated with psychophysical stress. In 2009, Wong et al. [3] revealed that patients with $H p$-negative idiopathic bleeding ulcers, in the pathogenesis of which mental stress might play an important role, had a high risk of mortality and recurrent bleeding.

Along these lines, we report the cases of two patients with psychological stress-induced hemorrhagic gastric ulcers in whom $H p$ had been successfully eradicated.

\footnotetext{
* Correspondence: moriyami@pop21.odn.ne.jp

'Department of Psychosomatic Internal Medicine, Health Sciences University of Hokkaido, Japan

Full list of author information is available at the end of the article
}

This case report surely provides clinically important information that psychological stress should also be considered in the management of patients with gastric ulcers.

\section{Case presentation}

\section{Case 1}

A 47-year-old Japanese man had been admitted to the hospital for hematemesis and tarry stools 14 years ago. He had a medical history of gastric ulcer and had received $H p$ eradication therapy two years before his current presentation. Since then, he had been taking the $\mathrm{H}_{2}$ blocker famotidine ( $40 \mathrm{mg} /$ day) for the prevention of ulcer recurrence. He denied use of NSAIDs or aspirin, smoking and drinking alcohol. Three days before his hospitalization he had been involved in a life-threatening accident in which his boat was overturned and he almost drowned. Afterward he was too agitated to sleep for the following three days. Laboratory findings showed mild anemia (hemoglobin $12.0 \mathrm{~g} / \mathrm{dL}$ ), elevated blood urea nitrogen (BUN) $(27.9 \mathrm{mg} / \mathrm{dL})$ and normal gastrin (150 $\mathrm{pg} / \mathrm{mL}$ ). An esophagogastroduodenoscopy demonstrated an open gastric ulcer with an exposed vessel (Figure 1A). We immediately performed endoscopic hemostasis procedures against the exposed vessel in the base of the 

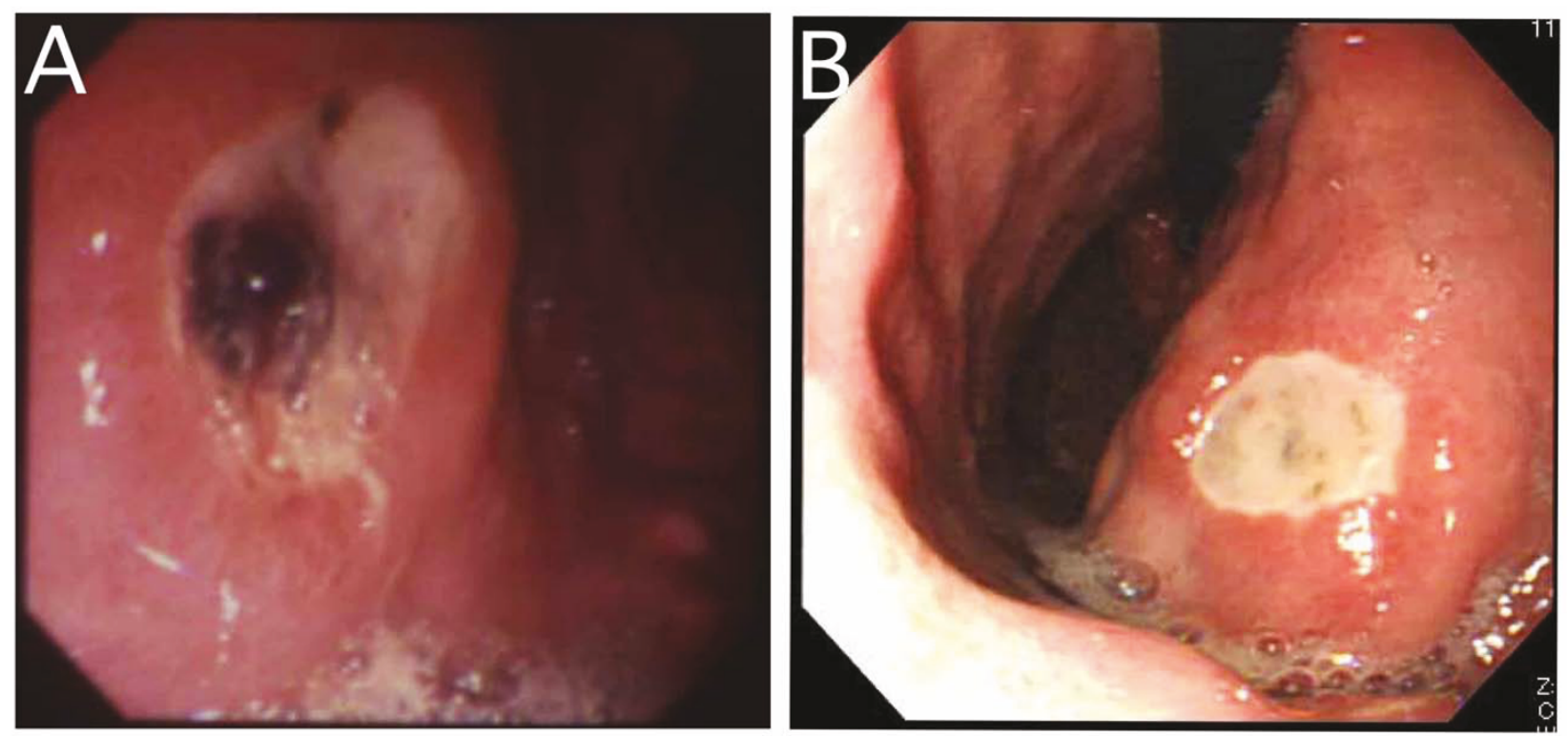

Figure 1 Esophagogastroduodenoscopic findings. (A) Case 1: An open gastric ulcer with an exposed vessel. (B) Case 2: A recurrent gastric ulcer without active bleeding.

gastric ulcer, using a heat probe coagulation method together with local injections of hypertonic saline epinephrine solution and absolute ethanol. The clinical course of the patient was uneventful after endoscopic therapy. Three $\mathrm{Hp}$-associated examinations, that is, rapid urease test, histology and bacteriology, were all negative. As to a mind-body correlation, the patient displayed a typical type A behavior pattern [4]. The psychophysical stress he experienced in the life-threatening boat accident was so enormous that he was extremely agitated and could hardly sleep. It was speculated that this strong emotional stress induced the recurrence of hemorrhagic gastric ulcer, even though he had been under maintenance therapy with $\mathrm{H}_{2}$ blockade after successful $\mathrm{Hp}$ eradication.

\section{Case 2}

A 69-year-old Japanese man visited our hospital seven years ago because of repeated tarry stools. In the previous year, he had developed a gastric ulcer and underwent $H p$ eradication therapy. He did not take NSAIDs or aspirin or drink alcohol, but he smoked an average of 20 cigarettes daily. Before he noticed tarry stools, he had been requested to edit a booklet for a community meeting. He was computer-illiterate and totally unaccustomed to such a task. He could manage to finish it by the deadline, but he developed tarry stools. He reported that his smoking pattern, including the number of cigarettes per day, was unchanged during the stressful period. Laboratory data demonstrated mild anemia (hemoglobin $11.1 \mathrm{~g} / \mathrm{dL})$, elevated BUN (33.1 $\mathrm{mg} / \mathrm{dL})$ and normal gastrin $(25 \mathrm{pg} / \mathrm{mL})$, suggesting the possible presence of gastrointestinal bleeding. Esophagogastroduodenoscopy revealed a recurrent gastric ulcer without active bleeding (Figure 1B). The absence of $H p$ infection was confirmed by negative ${ }^{13} \mathrm{C}$-urea breath test, histology and $H p$ antibody. The psychological assessment of the patient profile demonstrated that he was strict with regard to punctuality and had a strong sense of responsibility. These characteristics forced him to complete the task in which he was inexperienced by the deadline. It was therefore considered that his intense emotional stress resulted in his recurrent gastric ulcer.

\section{Discussion}

Although it is well-established that $H p$ infection is the most important pathogenic factor in peptic ulceration, it has been reported that ulcer recurrence occurs even after $\mathrm{Hp}$ eradication. A meta-analysis of seven trials conducted in the United States showed that $20 \%$ of patients had recurrent ulcers within six months despite successful cure of $H p$ infection and no reported use of NSAIDs [5]. A similar Japanese study revealed a recurrence rate of 3\% 48 months after successful $H p$ eradication [6].

The mechanism by which ulcer recurrence takes place in $\mathrm{Hp}$-negative patients remains to be clarified, but psychological stress may be associated with its recurrence. In fact, it should be noted that the incidence of bleeding gastric ulcers significantly increased after the Hanshin-Awaji earthquake in Japan [7]. It has also been demonstrated that psychophysical stress contributed to duodenal ulcer formation among $15.7 \%$ of $H p$-negative ulcer patients [2]. 
Since Selye [1] reported that stress produced the same symptoms, that is, peptic ulcer, adrenal hypertrophy and thymus atrophy, stress has been considered an important factor in the pathogenesis of ulcer formation. In fact, it has been well-documented that physical stress encountered in the intensive care unit can induce peptic ulcer bleeding among $\mathrm{Hp}$-negative patients [8-10]. On the other hand, our two patients developed hemorrhagic gastric ulcers due to psychological stress rather than to physical pathologies. In other words, our findings strongly indicate that not only physical but also psychological stressors can cause ulcer bleeding in spite of $H p$ negativity.

\section{Conclusion}

In conclusion, our case reports suggest that psychological stress is still an important clinical factor for peptic ulceration. In the management of patients with peptic ulcer, physicians should pay attention to the possible presence of psychological stress as well as physical causes.

\section{Consent}

Written informed consent was obtained from the patients for publication of this case report and any accompanying images. A copy of the written consent is available for review by the Editor-in-Chief of this journal.

\section{Author details}

1Department of Psychosomatic Internal Medicine, Health Sciences University of Hokkaido, Japan. ${ }^{2}$ Uehara Clinic, Sapporo, Japan. ${ }^{3}$ Department of General Medicine, Asahikawa Medical College, Asahikawa, Japan. ${ }^{4}$ Department of Internal Medicine, Asahikawa Medical College, Asahikawa, Japan.

\section{Authors' contributions}

MM, AU, TO and MM drafted the manuscript and designed the case report. All authors read and approved the final manuscript.

\section{Competing interests}

The authors declare that they have no competing interests.

Received: 4 February 2010 Accepted: 29 June 2011

Published: 29 June 2011

\section{References}

1. Selye H: A syndrome produced by diverse nocuous agents. Nature 1936 138:32-33.

2. Chen TS, Chang FY: Clinical characteristics of Helicobacter pylori-negative duodenal ulcer disease. Hepatogastroenterology 2008, 55:1615-1618.

3. Wong GL, Wong WW, Chan Y, Ching JY, Au K, Hui AJ, Lai LH, Chow DK, Siu DK, Lui YN, Wu JC, To KF, Hung LC, Chan HL, Sung JJ, Chan FK: High incidence of mortality and recurrent bleeding in patients with Helicobacter pylori-negative idiopathic bleeding ulcers. Gastroenterology 2009, 137:525-531.

4. Friedman M, Rosenman RH: Association of specific overt behavior pattern with blood and cardiovascular findings; blood cholesterol level, blood clotting time, incidence of arcus senilis, and clinical coronary artery disease. J Am Med Assoc 1959, 169:1286-1296.

5. Laine L, Hopkins RJ, Girardi LS: Has the impact of Helicobacter pylori therapy on ulcer recurrence in the United States been overstated? A meta-analysis of rigorously designed trials. Am J Gastroenterol 1998, 93:1409-1415.

6. Miwa H, Sakaki N, Sugano K, Sekine H, Higuchi K, Uemura N, Kato M, Murakami K, Kato C, Shiotani A, Ohkusa T, Takagi A, Aoyama N, Haruma K, Okazaki K, Kusugami K, Suzuki M, Joh T, Azuma T, Yanaka A, Suzuki H, Hashimoto H, Kawai T, Sugiyama T: Recurrent peptic ulcers in patients following successful Helicobacter pylori eradication: a multicenter study of 4,940 patients. Helicobacter 2004, 9:9-16.

7. Aoyama N, Kinoshita Y, Fujimoto S, Himeno S, Todo A, Kasuga M, Chiba T: Peptic ulcers after the Hanshin-Awaji earthquake: increased incidence of bleeding gastric ulcers. Am J Gastroenterol 1998, 93:311-316.

8. Schilling D, Haisch G, Sloot N, Jakobs R, Saggau W, Riemann JF: Low seroprevalence of Helicobacter pylori infection in patients with stress ulcer bleeding: a prospective evaluation of patients on a cardiosurgical intensive care unit. Intensive Care Med 2000, 26:1832-1836.

9. Halm U, Halm F, Thein D, Mohr FW, Mössner J: Helicobacter pylori infection: a risk factor for upper gastrointestinal bleeding after cardiac surgery? Crit Care Med 2000, 28:110-113.

10. Robert R, Gissot V, Pierrot M, Laksiri L, Mercier E, Prat G, Villers D, Vincent JF, Hira M, Vignon P, Charlot P, Burucoa C: Helicobacter pylori infection is not associated with an increased hemorrhagic risk in patients in the intensive care unit. Crit Care 2006, 10:R77.

doi:10.1186/1752-1947-5-252

Cite this article as: Moriya et al:: Stress-induced hemorrhagic gastric ulcer after successful Helicobacter pylori eradication: two case reports. Journal of Medical Case Reports 2011 5:252.

\section{Submit your next manuscript to BioMed Central and take full advantage of:}

- Convenient online submission

- Thorough peer review

- No space constraints or color figure charges

- Immediate publication on acceptance

- Inclusion in PubMed, CAS, Scopus and Google Scholar

- Research which is freely available for redistribution

Submit your manuscript at www.biomedcentral.com/submit 